\title{
ANALISIS KEBERLANJUTAN USAHATANI KOPI SERTIFIKASI COMMON CODE FOR THE COFFEE COMMUNITY (4C) DI KABUPATEN TANGGAMUS PROVINSI LAMPUNG
}

\author{
(Sustainability Analysis of Coffee Certification Common Code for The Coffee Community (4C) in \\ Tanggamus Regency of Lampung Province)
}

Gita Marindra, Bustanul Arifin, Yaktiworo Indriani

Jurusan Agribisnis, Fakultas Pertanian, Universitas Lampung, Jl. Prof. Dr. Soemantri Brodjonegoro No. 1

Bandar Lampung 35145, Telp. 085768212527, e-mail: gitamarindra@gmail.com

\begin{abstract}
This research aims to analyze farming income and sustainability of farming practices of coffee certification farmers and coffee non-certification farmers in Tanggamus Regency. This research used survey method. The numbers of samples in this research were 44 respondents of certification farmers and 24 respondents of non-certification farmers. The data was collected from August 2017 to November 2017. The data was analyzed by quantitative and qualitative descriptive analysis. The results showed that farming income of certification farmers were higher than non-certification farmers. Socially and environmental sustainable farming practices of certification farmers were more sustainable than non-certification farmers. Sustainability of economy, social and environmental aspects of certification farmers were more sustainable than non-certification farmers. Total of farming income of certification farmers and non-certification farmers were Rp16,330,309 per hectare and Rp10,637,482 per hectare. About 93.20\% of certification farmers's farming were sustainable, while about $91.70 \%$ of non-certification farmers's farming were quite sustainable.
\end{abstract}

Key words: certification, coffee, farming, sustainability

\section{PENDAHULUAN}

Kopi merupakan komoditas tropis utama yang diperdagangkan di seluruh dunia dengan kontribusi setengah dari total ekspor komoditas tropis. Pada tahun 2013, Indonesia tercatat sebagai produsen kopi terbesar ke tiga di dunia setelah Brazil dan Vietnam. Meskipun demikian, ekspor kopi dari Indonesia diperkirakan tidak lebih banyak daripada ekspor kopi Brazil, Vietnam dan Kolombia. Berdasarkan keunikan cita rasa dan aroma kopi asal Indonesia, Indonesia memiliki peluang besar untuk meningkatkan perdagangan kopi di dunia (Kementerian Pertanian 2016).

Indonesia memiliki beberapa provinsi terbesar yang memproduksi kopi, salah satunya adalah Provinsi Lampung. Provinsi Lampung terkenal dengan produksi karet dan kopinya, hal ini didukung oleh produksi kedua jenis tanaman perkebunan tersebut (Badan Pusat Statistik Provinsi Lampung 2017).

Tiga kabupaten/kota penghasil kopi tertinggi di Provinsi Lampung adalah Kabupaten Lampung Barat, Tanggamus dan Lampung Utara. Kabupaten Lampung Barat memproduksi kopi sebesar 52.648 ton. Kabupaten Tanggamus memproduksi kopi sebesar 27.581 ton. Kabupaten Lampung Utara memproduksi kopi sebesar 11.021 ton (Badan Pusat Statistik Provinsi Lampung 2017). Berdasarkan kontribusi Provinsi Lampung yang besar dalam memproduksi kopi, maka kopi Lampung berpotensi untuk memasuki pasar kopi internasional.

Negara konsumen kopi di pasar internasional menuntut kopi yang berkualitas dan aman bagi kesehatan. Tuntutan negara - negara tersebut diwujudkan dalam kopi yang bersertifikat. Sertifikasi kopi adalah proses dimana pihak ketiga memverifikasi pemenuhan standar dengan melakukan budidaya kopi yang baik dan benar sesuai dengan standar yang telah ditentukan pemberi sertifikasi, sehingga mutu dan kualitas kopi terjamin. Beberapa lembaga sertifikasi dunia telah melakukan sertifikasi kopi di Indonesia antara lain Organic, Fair Trade, UTZ, Rain Forest Alliance, Bird Friendly dan Common Code for the Coffee Community (4C) (Ardiyani dan Erdiansyah 2012).

Berdasarkan tuntutan pasar internasional tersebut, maka diperlukan adanya sertifikasi kopi agar kopi Lampung dapat diterima di pasar internasional. Salah satu sertifikasi kopi yang telah diterapkan di 
Provinsi Lampung adalah sertifikasi 4C. Petani kopi yang telah mendapatkan sertifikasi kopi adalah petani kopi di Kabupaten Tanggamus. Elemen pokok dalam sertifikasi $4 \mathrm{C}$ adalah aspek ekonomi, sosial dan lingkungan. Ketiga aspek tersebut berkaitan erat dengan penerapan pertanian secara berkelanjutan.

Pertanian berkelanjutan adalah pertanian yang dapat memenuhi kebutuhan generasi di masa sekarang, tanpa membahayakan kemampuan generasi di masa mendatang untuk memenuhi kebutuhannya. Pertanian berkelanjutan mencakup tiga aspek yaitu aspek ekonomi, sosial dan lingkungan. Berdasarkan uraian tersebut, maka penelitian ini bertujuan untuk menganalisis pendapatan usahatani kopi, praktik usahatani kopi yang berkelanjutan secara sosial dan praktik usahatani kopi yang berkelanjutan secara lingkungan.

\section{METODE PENELITIAN}

Metode yang digunakan dalam penelitian ini adalah survei. Penelitian dilakukan di Kabupaten Tanggamus, tepatnya di Kecamatan Pulau Panggung dan Air Naningan secara sengaja (purposive) dengan pertimbangan bahwa sebagian besar petani kopi di daerah tersebut telah menerapkan sertifikasi 4C dalam kurun waktu kurang lebih dua tahun. Metode pengambilan sampel petani kopi sertifikasi adalah secara acak kelompok (cluster random sampling), sedangkan metode pengambilan sampel petani nonsertifikasi secara sensus. Jumlah responden terdiri dari 44 petani sertifikasi dan 24 petani nonsertifikasi.

Pengumpulan data dilakukan pada bulan Agustus sampai November 2017. Data terdiri dari data primer yang diperoleh melalui wawancara dengan responden dan data sekunder diperoleh dari institusi yang berkaitan dengan penelitian. Data analisis secara kuantitatif untuk menjawab tiga tujuan dalam penelitian, dan dianalisis deskriptif kualitatif untuk menjelaskan hasil penelitian usahatani kopi yang berkelanjutan berdasarkan aspek ekonomi, sosial dan lingkungan.

Pendapatan usahatani adalah selisih antara penerimaan dan semua biaya. Rumus pendapatan usahatani yang dikemukakan oleh Soekartawi (1995) adalah sebagai berikut.

$$
\mathrm{Pd}=\mathrm{TR}-\mathrm{TC}
$$

Keterangan:

$\mathrm{Pd}=$ Pendapatan usahatani $(\mathrm{Rp})$

$\mathrm{TR}=$ Total penerimaan (tanaman kopi, tanaman naungan dan tanaman tumpang sari (Rp))

$\mathrm{TC}=$ Total biaya $(\operatorname{tanaman}$ kopi, tanaman naungan dan tanaman tumpang sari (Rp))

Untuk mengetahui apakah suatu usahatani menguntungkan atau tidak, dilakukan analisis R/C rasio, yaitu perbandingan (nisbah) total penerimaan terhadap total biaya. Rumus untuk menghitung nilai $\mathrm{R} / \mathrm{C}$ rasio adalah sebagai berikut.

$\mathrm{R} / \mathrm{C}=\mathrm{TR} / \mathrm{TC}$

Keterangan:

$\mathrm{R} / \mathrm{C}=$ Nisbah penerimaan dan biaya

$\mathrm{TR}=$ Total penerimaan (tanaman kopi, tanaman naungan dan tanaman tumpang sari (Rp))

$\mathrm{TC}=$ Total biaya $(\operatorname{tanaman}$ kopi, tanaman naungan dan tanaman tumpang sari (Rp))

Kriteria pengukuran dalam $\mathrm{R} / \mathrm{C}$ rasio adalah jika $\mathrm{R} / \mathrm{C}>1$ artinya usahatani mengalami keuntungan, jika $\mathrm{R} / \mathrm{C}<1$ artinya usahatani mengalami kerugian, jika $\mathrm{R} / \mathrm{C}=1$ artinya usahatani mengalami impas (tidak untung dan tidak rugi).

Uji beda Independent Samples t-test dilakukan untuk melihat ada tidaknya perbedaan antara pendapatan usahatani petani sertifikasi dan petani nonsertifikasi. Uji ini dilakukan dengan menggunakan SPSS 16 sebagai alat bantu perhitungan.

Penilaian praktik penerapan usahatani yang berkelanjutan menggunakan indikator kode perilaku 4C. Pengukuran indikator menggunakan skor, yaitu skor 1 apabila tidak sesuai standar, skor 2 apabila kurang sesuai standar dan skor 3 apabila sesuai standar. Hasil penilaian indikator dianalisis dengan mengggunakan uji Mann Whitney U-test untuk melihat ada tidaknya perbedaan antara praktik penerapan usahatani yang berkelanjutan petani sertifikasi dan petani nonsertifikasi. Uji validitas dan reliabilitas pertanyaan untuk membantu menjawab tujuan penelitian telah dilakukan.

Keberlanjutan usahatani kopi ditinjau berdasarkan tiga aspek yaitu aspek ekonomi, aspek sosial dan aspek lingkungan. Keberlanjutan usahatani kopi diukur dengan menggunakan indeks keberlanjutan. Rumus indeks keberlanjutan adalah sebagai berikut. 
Indeks keberlanjutan $=\frac{\text { skor yang diperoleh }}{\text { skor maksimum }} \times 100 \%$..

Indeks keberlanjutan diklasifikasikan menjadi empat kategori status keberlanjutan sebagai berikut (Thamrin et al 2007).

$\begin{array}{lll}\text { 1. } 0-25,00 \% & \text { : Tidak berkelanjutan (buruk) } \\ \text { 2. } 25,01-50,00 \% & \begin{array}{l}\text { : Kurang } \\ \text { (kurang) }\end{array} \\ \text { 3. } 50,01-75,00 \% & \text { : Cukup } \\ \text { (cukup) } & \text { berkelanjutan } \\ \text { 4. } 75,01-100,00 \% & \text { : Berkelanjutan (baik) }\end{array}$

\section{HASIL DAN PEMBAHASAN}

\section{Karakteristik Responden}

Petani kopi sertifikasi $(86,40 \%)$ tergolong kategori usia muda (21-39 tahun) dan kategori usia sedang (40-58 tahun), sedangkan petani kopi nonsertifikasi $(50,00 \%)$ tergolong kategori usia muda. Petani sertifikasi didominasi tamatan SMP (40,90\%), sedangkan petani nonsertifikasi didominasi tamatan SD $(45,80 \%)$. Jumlah tanggungan keluarga berkisar 4-5 orang, yaitu masing-masing petani sertifikasi $(47,70 \%)$ dan petani nonsertifikasi $(54,20 \%)$.

Petani kopi sertifikasi $(56,80 \%)$ berpengalaman usahatani kopi antara 3-18 tahun. Petani kopi nonsertifikasi $(45,80 \%)$ berpengalaman usahatani kopi antara 3-18 tahun dan 19-34 tahun. Luas lahan petani responden berkisar antara 0,25-1,83, yaitu masing-masing petani sertifikasi $(65,90 \%)$ dan petani nonsertifikasi $(87,50 \%)$. Petani kopi sertifikasi dan nonsertifikasi melakukan usahatani pada lahan milik sendiri yaitu masing-masing sebesar $100,00 \%$ dan $70,80 \%$.

\section{Pendapatan Usahatani Petani Responden}

Rata-rata produksi kopi petani sertifikasi sebesar $609 \mathrm{~kg} / \mathrm{ha}$ dengan rata-rata harga kopi sebesar Rp22.682, sedangkan rata-rata produksi kopi petani nonsertifikasi sebesar $669 \mathrm{~kg} / \mathrm{ha}$ dengan rata-rata harga kopi sebesar Rp22.267. Penerimaan usahatani terdiri dari penerimaan kopi, tanaman tumpang sari dan tanaman naungan. Total penerimaan usahatani petani kopi sertifikasi lebih tinggi dibandingkan petani kopi nonsertifikasi, yaitu masing-masing sebesar Rp21.052.367 dan Rp19.021.250 per hektar per tahun.
Tabel 2 menunjukkan jenis tanaman tumpang sari dan tanaman naungan yang ditanam di kebun petani responden. Tanaman tersebut bernilai ekonomi yang cukup tinggi. Hal tersebut berperan penting dalam menambah pendapatan usahatani petani selain pendapatan dari usahatani kopi. Biaya usahatani terdiri dari biaya tunai dan biaya diperhitungkan. Total biaya usahatani petani sertifikasi lebih rendah dibandingkan petani nonsertifikasi, yaitu biaya total usahatani petani sertifikasi sebesar Rp4.722.059, sedangkan petani nonsertifikasi sebesar Rp8.383.768 per hektar per tahun. Hal ini dikarenakan petani nonsertifikasi menggunakan banyak pestisida kimia dan tenaga kerja terutama tenaga kerja dalam keluarga.

Tabel 1. Rata-rata pendapatan usahatani petani kopi sertifikasi dan nonsertifikasi di Kabupaten Tanggamus (Rp per hektar)

\begin{tabular}{|c|c|c|}
\hline Keterangan & $\begin{array}{c}\text { Petani } \\
\text { Sertifikasi }\end{array}$ & $\begin{array}{c}\text { Petani } \\
\text { Nonsertifikasi }\end{array}$ \\
\hline \multicolumn{3}{|l|}{ Penerimaan } \\
\hline Kopi & 13.839 .072 & 14.876 .667 \\
\hline Tumpang Sari & 6.805 .432 & 4.048 .750 \\
\hline Naungan & 407.864 & 95.833 \\
\hline $\begin{array}{l}\text { Total Penerimaan } \\
\text { Usahatani }\end{array}$ & 21.052 .367 & 19.021 .250 \\
\hline \multicolumn{3}{|l|}{ Biaya } \\
\hline \multicolumn{3}{|l|}{ Biaya Tunai } \\
\hline - Pupuk Urea & 269.886 & 302.222 \\
\hline - Pupuk NPK Mutiara & 268.977 & 72.222 \\
\hline - Pupuk NPK Phonska & 198.148 & 255.694 \\
\hline - Pupuk KCl & 20.038 & 23.333 \\
\hline - Pupuk TSP & 56.818 & 41.250 \\
\hline - Pupuk SP36 & 41.591 & 44.167 \\
\hline - Pupuk ZA & 2.841 & 12.500 \\
\hline - Pupuk Kandang & 503.254 & 237.778 \\
\hline - Pupuk Kompos & 5.841 & - \\
\hline - Pestisida & 232.483 & 568.456 \\
\hline $\begin{array}{l}\text { - Tenaga Kerja Luar } \\
\text { Keluarga }\end{array}$ & 980.161 & 2.019 .835 \\
\hline - Pajak & 26.583 & 32.403 \\
\hline - Pengangkutan & 8.093 & 9.215 \\
\hline - Penggilingan & 135.269 & 148.704 \\
\hline Total Biaya Tunai & 2.749 .984 & 3.767 .780 \\
\hline \multicolumn{3}{|l|}{ Biaya Diperhitungkan } \\
\hline - Penyusutan Alat & 151.620 & 140.380 \\
\hline $\begin{array}{l}\text { - Tenaga Kerja Dalam } \\
\text { Keluarga }\end{array}$ & 1.820 .455 & 4.475 .608 \\
\hline $\begin{array}{l}\text { Total Biaya } \\
\text { Diperhitungkan }\end{array}$ & 1.972 .075 & 4.615 .988 \\
\hline Total Biaya Usahatani & 4.722 .059 & 8.383 .768 \\
\hline \multicolumn{3}{|l|}{ Pendapatan Usahatani } \\
\hline Atas Biaya Tunai & 18.302 .384 & 15.253 .470 \\
\hline Atas Biaya Total & 16.330 .309 & 10.637 .482 \\
\hline R/C Atas Biaya Tunai & 7,66 & 5,05 \\
\hline R/C Atas Biaya Total & 4,46 & 2,27 \\
\hline
\end{tabular}


Tabel 2. Rata-rata penerimaan usahatani petani kopi sertifikasi dan nonsertifikasi di Kabupaten Tanggamus

\begin{tabular}{|c|c|c|c|c|c|c|}
\hline \multirow[t]{2}{*}{ Keterangan } & \multicolumn{3}{|c|}{ Petani Sertifikasi } & \multicolumn{3}{|c|}{ Petani Nonsertifikasi } \\
\hline & Produksi $(\mathrm{Kg})$ & Harga (Rp/kg) & Penerimaan $(\mathrm{Rp})$ & Produksi (Kg) & Harga (Rp/kg) & Penerimaan (Rp) \\
\hline Kopi & 609 & 22.682 & 13.839 .072 & 669 & 22.267 & 14.876 .667 \\
\hline Jumlah & & & 13.839 .072 & & & 14.876 .667 \\
\hline Tumpang Sari & & & & & & \\
\hline Lada & 109 & 45.764 & 5.118 .977 & 56 & 42.567 & 2.372 .083 \\
\hline Pisang & 962 & 721 & 695.182 & 1.640 & 855 & 1.460 .000 \\
\hline Kakao & 47 & 20.500 & 991.273 & 11 & 15.000 & 166.667 \\
\hline Cabai & - & - & - & 2 & 30.000 & 50.000 \\
\hline Jumlah & & & 6.805 .432 & & & 4.048 .750 \\
\hline Naungan & & & & & & \\
\hline Jengkol & 26 & 12.917 & 311.652 & 1 & 15.000 & 12.500 \\
\hline Pete & 1 & 30.000 & 20.455 & - & - & \\
\hline Sengon & 0,08 & 1.000 .000 & 75.758 & 0,08 & 1.000 .000 & 83.333 \\
\hline Jumlah & & & 407.864 & & & 95.833 \\
\hline
\end{tabular}

Berdasarkan Tabel 1, rata-rata pendapatan usahatani atas biaya total petani sertifikasi lebih tinggi daripada petani nonsertifikasi, yaitu petani sertifikasi sebesar Rp16.330.309, sedangkan petani nonsertifikasi sebesar Rp10.637.482 per hektar per tahun. $\mathrm{R} / \mathrm{C}$ rasio atas biaya total petani sertifikasi lebih besar daripada petani nonsertifikasi, yaitu masing-masing sebesar 4,46 dan 2,27. $\mathrm{R} / \mathrm{C}$ rasio atas biaya total petani sertifikasi sebesar 4,46 artinya setiap Rp1,00 biaya yang dikeluarkan oleh petani akan memperoleh penerimaan sebesar $\mathrm{Rp} 4,46$. $\mathrm{R} / \mathrm{C}$ rasio atas biaya total petani nonsertifikasi sebesar 2,27 artinya setiap $\mathrm{Rp} 1,00$ biaya yang dikeluarkan oleh petani akan memperoleh penerimaan sebesar Rp2,27. R/C rasio atas biaya total usahatani petani responden bernilai $>1$, hal ini menunjukkan bahwa usahatani mengalami keuntungan dan layak untuk dilaksanakan. Hasil penelitian ini sejalan dengan penelitian yang dilakukan Prasmatiwi et al (2010), bahwa usahatani kopi di Kabupaten Lampung Barat layak untuk dilaksanakan.

Hasil uji beda pendapatan usahatani menunjukkan terdapat perbedaan yang signifikan antara pendapatan usahatani petani kopi sertifikasi dan nonsertifikasi. Hasil uji ini sejalan dengan penelitian yang dilakukan oleh Incamilla, Arifin dan Nugraha (2015), bahwa terdapat perbedaan signifikan antara pendapatan usahatani petani kopi sertifikasi dan nonsertifikasi. Terdapat perbedaan antara pendapatan usahatani petani sertifikasi dengan pendapatan usahatani petani nonsertifikasi, yang ditunjukkan dengan pendapatan usahatani petani sertifikasi yang lebih tinggi dibandingkan pendapatan usahatani petani nonsertifikasi.

\section{Praktik Usahatani Kopi yang Berkelanjutan}

\section{Praktik Usahatani Berkelanjutan Secara Ekonomi}

Data pada Tabel 3 menunjukkan hasil rata-rata skor penilaian praktik usahatani kopi yang berkelanjutan secara ekonomi petani sertifikasi lebih tinggi dibandingkan petani nonsertifikasi. Berdasarkan hal tersebut, manfaat ekonomi dari usahatani kopi berkelanjutan yang diterima petani sertifikasi lebih tinggi dibandingkan petani nonsertifikasi.

Tabel 3. Rata-rata skor dan hasil uji Mann Whitney $U$ penilaian praktik usahatani secara ekonomi di Kabupaten Tanggamus

\begin{tabular}{|c|c|c|}
\hline \multirow[t]{2}{*}{ Indikator } & $\begin{array}{c}\text { Petani } \\
\text { Sertifikasi }\end{array}$ & $\begin{array}{c}\text { Petani } \\
\text { Nonsertifikasi } \\
\end{array}$ \\
\hline & Skor & Skor \\
\hline 1 Produktivitas usahatani kopi & 2,64 & 1,79 \\
\hline $\begin{array}{l}2 \text { Kemudahan dalam } \\
\text { memperoleh informasi pasar } \\
\text { berupa harga kopi yang sedang } \\
\text { berlaku }\end{array}$ & 2,82 & 2,04 \\
\hline 3 Harga jual kopi & 2,57 & 1,88 \\
\hline $\begin{array}{l}4 \text { Transparansi dalam penilaian } \\
\text { mutu kopi yang dihasilkan } \\
\text { (kadar air, cacat biji, dll) } \\
\text { sebagai pertimbangan harga } \\
\text { jual kopi }\end{array}$ & 2,77 & 1,88 \\
\hline $\begin{array}{l}5 \text { Kemudahan dalam pemasaran } \\
\text { kopi }\end{array}$ & 2,68 & 2,38 \\
\hline Total & 13,48 & 9,96 \\
\hline Indeks Keberlanjutan (\%) & 89,85 & 66,39 \\
\hline Mann Whitney $U$ & & 00 \\
\hline Signifikansi & & 00 \\
\hline
\end{tabular}


Petani sertifikasi di lokasi penelitian telah menjadi petani sertifikasi 4C selama kurang lebih 2 tahun. Petani sertifikasi mendapatkan pembinaan dan penyuluhan (Sekolah Lapang) tentang budidaya kopi yang berkelanjutan secara baik dan benar. Selain belajar secara teori, petani sertifikasi juga diajarkan penerapan langsung di kebun kopi, sehingga petani sertifikasi merasakan produktivitas kopi perlahan-lahan mulai meningkat. Selama musim panen, petani sertifikasi akan menerima Short Message Service (SMS) dari pihak Kelompok Usaha Bersama (KUB) yang berisikan harga kopi yang sedang berlaku. Hal tersebut membuat petani sertifikasi merasakan kemudahan dalam memperoleh informasi pasar berupa perkembangan harga kopi yang sedang berlaku.

Petani sertifikasi bekerja sama dengan KUB melalui sistem langganan, namun KUB tidak mengikat petani sertifikasi. Petani sertifikasi dapat juga menjual hasil produksi kopi ke tengkulak. Berdasarkan hasil penelitian, rata-rata perbedaan harga jual kopi di KUB tidak berbeda jauh dengan di tengkulak yaitu hanya berkisar Rp400. Petani sertifikasi mendapatkan premium fee dari KUB yaitu sebesar Rp200 per kilogram. Hasil premium fee akan didapatkan oleh petani sertifikasi setiap akhir tahun. Premium fee akan diserahkan kepada ketua kelompok tani, selanjutnya masing-masing kelompok tani akan bermusyawarah bagaimana premium fee akan dimanfaatkan.

Sistem penentuan harga jual kopi sertifikasi dilakukan secara transparan oleh pihak KUB. Harga jual kopi didasarkan atas beberapa indikator, seperti kadar air kopi, banyaknya kopi yang cacat (defect), rendemen kopi, uji cita rasa kopi dan kebersihan kopi.

Petani sertifikasi tidak merasakan adanya perbedaan dalam pemasaran kopi sebelum bergabung menjadi petani binaan KUB. Hal ini dikarenakan bila petani sertifikasi ingin menjual kopi, mereka tetap perlu mendatangi KUB ataupun tengkulak, sehingga tetap mengeluarkan biaya pengangkutan.

Di sisi lain, petani nonsertifikasi melakukan budidaya kopi sesuai pengetahuan petani masingmasing, tanpa mengetahui apakah budidaya kopi tersebut sudah baik dan benar, sehingga petani nonsertifikasi merasakan produktivitas kopi tidak mengalami peningkatan. Petani nonsertifikasi menjual kopi kepada tengkulak.
Petani nonsertifikasi terkadang merasakan transparansi harga jual kopi, namun tergantung dengan tengkulak yang dipilih oleh petani. Ada tengkulak yang melihat berdasarkan kadar air kopi, namun ada beberapa yang tidak. Petani nonsertifikasi akan mendatangi tengkulak bila ingin menjual kopi, sehingga petani nonsertifikasi juga mengeluarkan biaya pengangkutan.

Hasil uji Mann Whitney $U$ penilaian praktik usahatani kopi yang berkelanjutan secara ekonomi menunjukkan bahwa terdapat perbedaan yang signifikan antara praktik usahatani kopi yang berkelanjutan secara ekonomi antara petani sertifikasi dan petani nonsertifikasi. Hasil penelitian ini sejalan dengan Juwita, Prasmatiwi dan Santoso (2014) bahwa petani kopi verifikasi mempunyai persepsi yang lebih tinggi mengenai manfaat ekonomi program verifikasi dibandingkan petani nonverifikasi.

\section{Praktik Usahatani Berkelanjutan Secara Sosial}

Tabel 4 menunjukkan rata-rata skor penilaian praktik usahatani kopi yang berkelanjutan secara sosial petani sertifikasi lebih tinggi dibandingkan petani nonsertifikasi. Berdasarkan hal tersebut, manfaat sosial dari usahatani kopi berkelanjutan yang diterima petani sertifikasi lebih tinggi dibandingkan petani nonsertifikasi.

Petani sertifikasi tergabung di dalam kelompok tani. Kelompok tani tersebut terdaftar sebagai kelompok tani binaan KUB. Kelompok tani binaan KUB mendapatkan SL sebanyak 6 kali dalam setahun. Sekolah Lapang memberikan petani sertifikasi pengetahuan tentang budidaya kopi yang baik dan berkelanjutan. Dilain sisi, petani nonsertifikasi tidak tergabung dalam kelompok tani. Hal ini menyebabkan tidak adanya kegiatan yang dapat membantu petani nonsertifikasi untuk menambah pengetahuan tentang budidaya kopi. Petani sertifikasi dan petani nonsertifikasi mengikuti kelompok masyarakat seperti kelompok arisan dan kelompok pengajian. Petani sertifikasi dan petani nonsertifikasi juga aktif dalam mengikuti kegiatan gotong royong di daerah lingkungan sekitar tempat tinggal. Anak berusia di bawah 15 tahun (atau dalam usia wajib sekolah) di lingkungan sekitar tempat tinggal petani sertifikasi dan petani nonsertifikasi mayoritas bersekolah serta jarang ada yang bekerja di kebun sebagai buruh tani. 
Tabel 4. Rata-rata skor dan hasil uji Mann Whitney $U$ penilaian praktik usahatani kopi yang berkelanjutan secara sosial di Kabupaten Tanggamus

\begin{tabular}{|c|c|c|}
\hline \multirow[t]{2}{*}{ Indikator } & $\begin{array}{c}\text { Petani } \\
\text { Sertifikasi }\end{array}$ & $\begin{array}{r}\text { Petani Non } \\
\text { Sertifikasi }\end{array}$ \\
\hline & Skor & Skor \\
\hline \multicolumn{3}{|l|}{ Partisipasi dalam Kelompok } \\
\hline \multicolumn{3}{|l|}{ Masyarakat } \\
\hline 1 Mengikuti kelompok tani & 3,00 & 1,00 \\
\hline $\begin{array}{l}2 \text { Keaktifan dalam mengikuti } \\
\text { kegiatan kelompok tani }\end{array}$ & 2,82 & 1,00 \\
\hline $\begin{array}{l}3 \text { Mengikuti kegiatan } \\
\text { kelompok masyarakat }\end{array}$ & 2,68 & 1,83 \\
\hline $\begin{array}{l}4 \text { Jumlah kelompok } \\
\text { masyarakat yang diikuti }\end{array}$ & 2,20 & 1,54 \\
\hline $\begin{array}{l}5 \text { Keaktifan dalam mengikuti } \\
\text { kegiatan kelompok } \\
\text { masyarakat }\end{array}$ & 2,61 & 1,83 \\
\hline $\begin{array}{l}6 \text { Keaktifan dalam kegiatan } \\
\text { gotong royong di lingkungan } \\
\text { sekitar }\end{array}$ & 2,86 & 2,67 \\
\hline \multicolumn{3}{|l|}{ Hak Masa Kanak-Kanak dan } \\
\hline \multicolumn{3}{|l|}{ Pendidikan } \\
\hline $\begin{array}{l}1 \text { Apakah anak usia < } 15 \text { tahun } \\
\text { di lingkungan sekitar } \\
\text { bersekolah }\end{array}$ & 2,68 & 2,54 \\
\hline $\begin{array}{l}2 \text { Apakah anak usia < } 15 \text { tahun } \\
\text { di lingkungan sekitar menjadi } \\
\text { buruh tani }\end{array}$ & 2,84 & 2,67 \\
\hline \multicolumn{3}{|l|}{ Kesehatan dan Keselamatan } \\
\hline \multicolumn{3}{|l|}{ Kerja } \\
\hline 1 Memiliki alat pelindung diri & 2,86 & 1,92 \\
\hline $\begin{array}{l}2 \text { Penggunaan alat pelindung } \\
\text { diri saat bekerja di kebun }\end{array}$ & 2,77 & 1,58 \\
\hline $\begin{array}{l}3 \text { Pembersihan limbah yang ada } \\
\text { setelah bekerja }\end{array}$ & 2,45 & 1,88 \\
\hline Total & 29,80 & 20,46 \\
\hline Indeks Keberlanjutan (\%) & 90,29 & 61,99 \\
\hline Mann Whitney $U$ & \multicolumn{2}{|c|}{11,000} \\
\hline Signifikansi & \multicolumn{2}{|c|}{0,000} \\
\hline
\end{tabular}

Hasil uji Mann Whitney $U$ penilaian praktik usahatani kopi yang berkelanjutan secara sosial menunjukkan bahwa terdapat perbedaan yang signifikan antara praktik usahatani kopi yang berkelanjutan secara sosial antara petani sertifikasi dan petani nonsertifikasi. Hasil penelitian ini sejalan dengan Oktami, Prasmatiwi dan Rosanti (2014) bahwa terdapat perbedaan yang signifikan antara praktik pengelolaan usahatani kopi petani sertifikasi dan petani nonsertifikasi terhadap manfaat sertifikasi dari aspek sosial.

\section{Praktik Usahatani Berkelanjutan Secara Lingkungan}

Berdasarkan Tabel 5, rata-rata skor penilaian praktik usahatani kopi yang berkelanjutan secara lingkungan petani sertifikasi lebih tinggi dibandingkan petani nonsertifikasi. Berdasarkan hal tersebut, manfaat lingkungan dari usahatani kopi berkelanjutan yang diterima petani sertifikasi lebih tinggi dibandingkan petani nonsertifikasi.

Petani sertifikasi membiarkan satwa liar apabila berkeliaran di kebun. Petani sertifikasi memiliki peta kebun sendiri. Petani sertifikasi melakukan konservasi keanekaragaman hayati dengan cara menanam lebih dari satu macam tanaman naungan dan tanaman sampingan, yang hasilnya membantu menambah pendapatan petani sertifikasi.

Petani sertifikasi menangani pestisida dan bahan kimia berbahaya lainnya dengan menggunakan alat pelindung diri. Petani sertifikasi telah mengurangi penggunaan pestisida kimia, sehingga penggunaan pestisida kimia tahun 2017 hanya sebesar 4,44 liter per tahun.

Dilain sisi, terkadang beberapa petani mengusir satwa liar di kebun. Petani nonsertifikasi tidak memiliki peta kebun sendiri. Petani nonsertifikasi juga menanam tanaman tumpang sari dan tanaman naungan. Masih banyak petani nonsertifikasi yang menggunakan pestisida daftar merah $4 \mathrm{C}$ dan pestisida daftar kuning 4C tidak diminimalkan penggunaannya. Penggunaan pestisida pada tahun 2017 cukup besar yaitu 11,15 liter per tahun. Petani nonsertifikasi tidak menerapkan sistem PHT di kebun.

Petani nonsertifikasi jarang menggunakan alat pelindung diri, apabila menangani pestisida dan bahan kimia lain. Mayoritas petani nonsertifikasi tidak membuat rorak dan terasering di kebun. Penggunaan pupuk di kebun tidak disesuaikan dengan kebutuhan tanaman dan masih tidak banyak menggunakan pupuk organik. Petani nonsertifikasi tidak memiliki dokumentasi pemupukan.

Hasil uji Mann Whitney $U$ penilaian praktik usahatani kopi yang berkelanjutan secara lingkungan menunjukkan bahwa terdapat perbedaan yang signifikan antara praktik usahatani kopi yang berkelanjutan secara lingkungan antara petani sertifikasi dan petani nonsertifikasi. Hasil penelitian ini sejalan dengan Fatmalasari, Prasmatiwi dan Rosanti (2016) bahwa rata-rata manfaat lingkungan yang diterima petani sertifikasi lebih tinggi dari manfaat lingkungan yang diterima petani nonsertifikasi. 
Tabel 5. Rata-rata skor dan hasil uji Mann Whitney $U$ praktik usahatani kopi secara lingkungan di Kabupaten Tanggamus

\begin{tabular}{|c|c|c|}
\hline \multirow[t]{2}{*}{ Indikator } & $\begin{array}{l}\text { Petani } \\
\text { Sertifi- } \\
\text { kasi } \\
\end{array}$ & $\begin{array}{c}\text { Petani } \\
\text { Nonser- } \\
\text { tifikasi } \\
\end{array}$ \\
\hline & Skor & Skor \\
\hline \multicolumn{3}{|l|}{ Konservasi Keanekaragaman } \\
\hline \multicolumn{3}{|l|}{ Hayati } \\
\hline $\begin{array}{l}1 \text { Yang dilakukan bila melihat } \\
\text { satwa liar di kebun }\end{array}$ & 2,75 & 2,38 \\
\hline 2 Memiliki peta kebun sendiri & 2,68 & 1,04 \\
\hline $\begin{array}{l}3 \text { Melakukan langkah dan tindakan } \\
\text { konservasi dengan cara menanam } \\
\text { bermacam tanaman tumpang } \\
\text { sari/naungan di kebun }\end{array}$ & 2,80 & 2,13 \\
\hline \multicolumn{3}{|l|}{ Penggunaan Pestisida } \\
\hline $\begin{array}{l}1 \text { Pengendalian hama, penyakit dan } \\
\text { gulma di kebun }\end{array}$ & 2,30 & 1,33 \\
\hline $\begin{array}{l}2 \text { Menggunakan pestisida daftar } \\
\text { merah dan daftar kuning } 4 \mathrm{C}\end{array}$ & 2,61 & 1,38 \\
\hline $\begin{array}{l}3 \text { Menggunakan sistem } \\
\text { pengendalian hama terpadu } \\
(\mathrm{PHT})\end{array}$ & 1,75 & 1,08 \\
\hline \multicolumn{3}{|l|}{ Penanganan Pestisida dan Bahan } \\
\hline \multicolumn{3}{|l|}{ Kimia Berbahaya Lain } \\
\hline $\begin{array}{l}1 \text { Cara menangani pestisida dan } \\
\text { bahan kimia berbahaya lain }\end{array}$ & 2,43 & 1,42 \\
\hline $\begin{array}{l}2 \text { Pengetahuan tentang pestisida } \\
\text { dan bahan kimia lain }\end{array}$ & 2,32 & 1,25 \\
\hline \multicolumn{3}{|l|}{ Konservasi Tanah } \\
\hline 1 Kebun pernah mengalami erosi & 2,75 & 2,29 \\
\hline 2 Kebun memiliki rorak & 2,43 & 1,50 \\
\hline 3 Membuat terasering di kebun & 2,36 & 1,92 \\
\hline \multicolumn{3}{|l|}{$\begin{array}{l}\text { Kesuburan Tanah dan Manajemen } \\
\text { Pupuk }\end{array}$} \\
\hline 1 Penggunaan pupuk di kebun & 2,48 & 1,67 \\
\hline $\begin{array}{l}2 \text { Memiliki dokumentasi } \\
\text { pemupukan }\end{array}$ & 1,66 & 1,00 \\
\hline \multicolumn{3}{|l|}{ Kesuburan Tanah dan Manajemen } \\
\hline \multicolumn{3}{|l|}{ Zat Organik } \\
\hline $\begin{array}{l}1 \text { Melakukan pemeliharaan zat } \\
\text { organik }\end{array}$ & 2,09 & 1,29 \\
\hline $\begin{array}{l}2 \text { Membuat pupuk dari limbah } \\
\text { organik }\end{array}$ & 2,11 & 1,38 \\
\hline \multicolumn{3}{|l|}{ Sumber Air } \\
\hline 1 Sumber air di dekat kebun dijaga & 2,48 & 1,33 \\
\hline 2 Menggunakan air dengan efisien & 2,36 & 1,33 \\
\hline \multicolumn{3}{|l|}{ Air Limbah } \\
\hline $\begin{array}{l}1 \text { Tempat membuang air bekas } \\
\text { cucian sprayer pestisida }\end{array}$ & 2,41 & 1,58 \\
\hline $\begin{array}{l}2 \text { Tempat membuang air limbah } \\
\text { rumah tangga }\end{array}$ & 2,77 & 1,79 \\
\hline \multicolumn{3}{|l|}{ Limbah Berbahaya } \\
\hline $\begin{array}{l}1 \text { Mengumpulkan bekas botol atau } \\
\text { sampah pestisida/pupuk dari } \\
\text { kebun }\end{array}$ & 2,45 & 2,04 \\
\hline $\begin{array}{l}2 \text { Perlakuan terhadap bekas botol } \\
\text { atau sampah pestisida/pupuk dari } \\
\text { kebun }\end{array}$ & 2,41 & 1,67 \\
\hline Total & 50,41 & 33,17 \\
\hline Indeks Keberlanjutan (\%) & 80,01 & 52,65 \\
\hline Mann Whitney $U$ & \multicolumn{2}{|c|}{12,500} \\
\hline Signifikansi & \multicolumn{2}{|c|}{0,000} \\
\hline
\end{tabular}

Tabel 6. Rata-rata nilai indeks keberlanjutan usahatani kopi di Kabupaten Tanggamus

\begin{tabular}{lcc}
\hline \multicolumn{1}{c}{ Indeks } & Petani & $\begin{array}{c}\text { Petani } \\
\text { Keberlanjutan }(\%)\end{array}$ \\
Sertifikasi & 89,85 & 66,39 \\
\hline Ekonomi & 90,29 & 61,99 \\
Sosial & 80,01 & 52,65 \\
Lingkungan & 84,40 & 57,28 \\
\hline Rata-rata & & \\
\hline
\end{tabular}

\section{Keberlanjutan Usahatani Kopi di Kabupaten Tanggamus}

Praktik pengelolaan usahatani kopi yang berkelanjutan diukur berdasarkan standar 4C, dengan 5 indikator tentang manfaat ekonomi, 11 indikator tentang manfaat sosial, serta 21 indikator tentang manfaat lingkungan. Berdasarkan Tabel 6, rata-rata nilai indeks keberlanjutan petani sertifikasi lebih tinggi dibandingkan petani nonsertifikasi. Petani sertifikasi memiliki indeks keberlanjutan aspek ekonomi, sosial dan lingkungan sebesar $84,40 \%$, artinya usahatani petani sertifikasi tergolong dalam kategori berkelanjutan. Petani nonsertifikasi memiliki indeks keberlanjutan aspek ekonomi, sosial dan lingkungan sebesar 57,28\%, artinya usahatani petani nonsertifikasi tergolong dalam kategori cukup berkelanjutan. Petani nonsertifikasi masih tergolong cukup berkelanjutan, karena praktik usahatani kopi secara lingkungan masih menggunakan pestisida dalam jumlah banyak. Nilai indeks keberlanjutan usahatani berdasarkan diagram layang dapat dilihat pada Gambar 1.

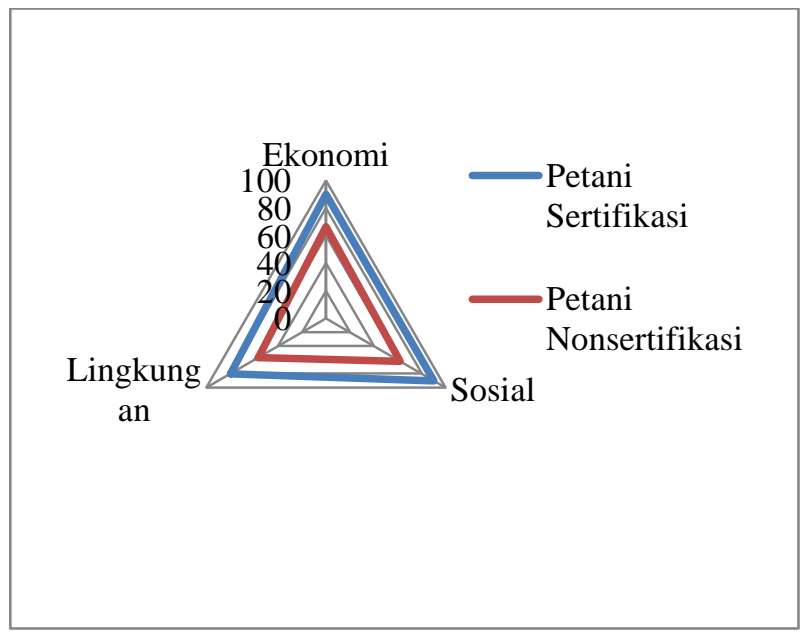

Gambar 1. Nilai indeks keberlanjutan aspek ekonomi, sosial dan lingkungan usahatani kopi di Kabupaten Tanggamus berdasarkan diagram layang 
Tabel 7. Keberlanjutan usahatani kopi di Kabupaten Tanggamus

\begin{tabular}{lcrrr}
\hline \multirow{2}{*}{ Status Keberlanjutan } & \multicolumn{2}{c}{$\begin{array}{c}\text { Petani } \\
\text { Sertifikasi }\end{array}$} & \multicolumn{2}{c}{$\begin{array}{c}\text { Petani } \\
\text { Nonsertifikasi }\end{array}$} \\
\cline { 2 - 5 } & $\begin{array}{l}\text { Jumlah } \\
\text { (orang) }\end{array}$ & Persen & $\begin{array}{c}\text { Jumlah } \\
\text { (orang) }\end{array}$ & Persen \\
\hline Tidak berkelanjutan & 0 & 0 & 0 & 0 \\
Kurang Berkelanjutan & 0 & 0 & 2,00 & 8,30 \\
Cukup Berkelanjutan & 3,00 & 6,80 & 22,00 & 91,70 \\
Berkelanjutan & 41,00 & 93,20 & 0 & 0 \\
\hline Jumlah & 44,00 & 100,00 & 24,00 & 100,00 \\
\hline
\end{tabular}

Tabel 7 menunjukkan bahwa status keberlanjutan aspek ekonomi, sosial dan lingkungan usahatani petani sertifikasi lebih berkelanjutan dibandingkan petani nonsertifikasi. Hal ini menunjukkan bahwa sertifikasi 4C telah memberikan manfaat yang berkelanjutan bagi usahatani kopi petani sertifikasi.

\section{KESIMPULAN}

Pendapatan usahatani petani kopi sertifikasi lebih tinggi dibandingkan petani nonsertifikasi, yaitu petani sertifikasi sebesar Rp16.330.309 per hektar dan petani nonsertifikasi sebesar Rp10.637.482 per hektar. Praktik usahatani kopi yang berkelanjutan secara sosial dan lingkungan petani sertifikasi lebih berkelanjutan dibandingkan petani nonsertifikasi. Secara keseluruhan, keberlanjutan aspek ekonomi, sosial dan lingkungan usahatani petani sertifikasi lebih berkelanjutan dibandingkan petani nonsertifikasi. Sebanyak 93,20\% usahatani petani sertifikasi tergolong berkelanjutan, sedangkan sebanyak $91,70 \%$ usahatani petani nonsertifikasi tergolong cukup berkelanjutan.

\section{DAFTAR PUSTAKA}

Ardiyani F dan Erdiansyah NP. 2012. Sertifikasi Kopi Berkelanjutan di Indonesia. Warta Pusat Penelitian Kopi dan Kakao Indonesia. Jember. https://anzdoc.com/download/sertifi kasi-kopi-berkelanjutan-di-indonesiapusat-pen elitian.html. [12 Oktober 2016].

BPS [Badan Pusat Statistik] Provinsi Lampung. 2017. Provinsi Lampung dalam Angka 2016. BPS Provinsi Lampung. Bandar Lampung. https://lampung.bps.go.id/publication/2016/07 /15/f1a4eb2ab6d60d35e1f52d50/provinsi-lam pung-dalam-angka-2016.html. [2 Januari 2017].

Fatmalasari M, Prasmatiwi FE, dan Rosanti N. 2016. Analisis manfaat sertifikasi indonesian organic farm certification (INOFICE) terhadap keberlanjutan usahatani kopi organik di Kecamatan Air Hitam Kabupaten Lampung Barat. JIIA, 4 (1) : 30-39. http://jurnal.fp. unila.ac.id/index.php/JIA/article/view/1212/1 109. [21 Februari 2017].

Incamilla A, Arifin B, dan Nugraha A. 2015. Keberlanjutan usahatani kopi agroforestri di Kecamatan Pulau Panggung Kabupaten Tanggamus. JIIA, 3 (3) : 260-267. http:// jurnal.fp.unila.ac.id/index.php/JIA/article/vie w/1050/955. [3 November 2016].

Juwita, T, Prasmatiwi FE, dan Santoso H. 2014. Manfaat finansial pembinaan dan verifikasi kopi dalam upaya peningkatan mutu kopi: studi kasus program verifikasi binaan PT Nestle Indonesia di Kabupaten Tanggamus. JIIA, 2 (3) : 276-284. http://jurnal.fp.unila. ac.id/index.php/JIA/article/view/811/741 . [5 November 2016]

Kementerian Pertanian. 2016. Outlook Kopi: Komoditas Pertanian Subsektor Perkebunan. Pusat Data dan Sistem Informasi Pertanian Sekretariat Jenderal - Kementerian Pertanian. Jakarta. http://epublikasi.setjen.pertanian.go. id/epublikasi/outlook/2016/Perkebunan/OUT LOOK\%20KOPI\%202016/files/assets/commo n/downloads/OUTLOOK\%20KOPI\%202016. pdf. [6 Januari 2017].

Oktami N, Prasmatiwi FE, dan Rosanti N. 2014. Manfaat sertifikasi rainforest alliance (RA) dalam mengembangkan usahatani kopi yang berkelanjutan di Kecamatan Pulau Panggung Kabupaten Tanggamus. JIIA, 2 (4) : 337-347. http://jurnal.fp.unila.ac.id/index.php/JIA/articl e /view/988/894. [10 November 2017].

Prasmatiwi FE, Irham, Suryantini A, dan Jamhari. 2010. Analisis keberlanjutan usahatani kopi di kawasan hutan Kabupaten Lampung Barat dengan Pendekatan Nilai Ekonomi Lingkungan. Jurnal Pelita Perkebunan, 26 (1) : 57-69. https://www.ccrjournal.com/ind ex.php/ccrj/article/download/117/pdf_31. [ 11 Juli 2018].

Soekartawi. 1995. Analisis Usahatani. UI-Press. Jakarta.

Thamrin, Sutjahjo, Herison, dan Sabiham. 2007. Analisis keberlanjutan wilayah perbatasan Kalimantan Barat-Malaysia untuk pengembangan kawasan agropolitan. Jurnal Agro Ekonomi, 25 (2) : 103-124. http://ejurnal .litbang.pertanian.go.id/index.php/jae/article/v i ew/4716/3982. [8 Januari 2017]. 